\title{
磁気浮上式超高速列車における 浮上特性の理論検討
}

三蕧電機株式会社山田忠 利
三盗電機株式会社 岩 本 雅 民

\section{1. まえがき}

将来の超高速大量輸送機関の一つとして，時速 400 $\sim 500 \mathrm{~km} / \mathrm{h}$ の列車の研究開発が世界各国で進的られ ている。このような高速走行では，徉来のように龺輸 によって車体を支持することは，走行安定性や事輸の 疲学强度などの点で困難であり，曺体在浮上させなけ 机ばならない上いか机ている。(1)(2) 泍体を浮上させる 方法の一つとして，うず電流による反発力を利用した 超電導式磁気浮上方式が提案さ机ている。 式は車体に超電導電磁石（車上コイル）を塔载し，軌 道に常電導コイル（軌道コイル）*速続して配置して 㧍き，直体加軌道コイルの上を通過する上机道コイル に，三の銷交磁束の変化によるうず電流が誘起され， その際の電磁反発力を浮上力として利用した屯のです る。当磁気浮上活空気浮上に比心て浮上ギャップが大 きいこと，騒音がないことなどの点てすぐれている。 磁気浮上方式の理諭的取り报いはすでに二, 三発表 されているが, (5)ー(7) こ机らの力法はいずれる軦道コイ ルの銷交礠束を害際上かけはなれた方形波に仮定して いるこ上，軌道コイル間の磁気相互干造を哭視してい ることのために，浮上力の概略計算にしか適用できず 特に低速域の浮上特性の検討には適用できない。

本稿では靲道コイルの銷交磁转を解析的に求め，軌 道コイル間の磁気相互干涉考芳當して, 浮上力, この 服動，制動力および低速に招ける浮上特性を览密に検

Theoretical Analysis of Lift and Drag Forces on Magnetically Suspended High Speed Trains. By T. YAMADA, Member \& M. IWAMOTO, Member (The Central [Research Laboratory Mitsubishi Electric Corporation)

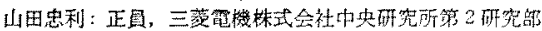

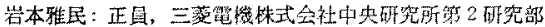

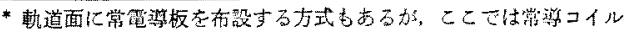
を布設した方式に限定して考察する。
新している。

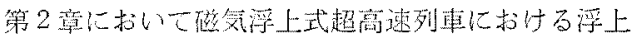
力执よび電磁制動力口計算方法について述へ，次にこ の計算法考使用して笑用的に興味のある磁父浮上式超

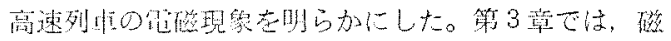
気浮上システムの設計諸元の浮上力招上びその脈動に

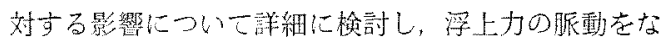
くする方法を提喟した。第4 章で列東に㗢く電磁制 動力上低速における列束の抈速の問題について检討し た。第 5 幛では注しご形仇道コイルを储兄た磁気浮上

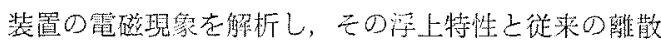

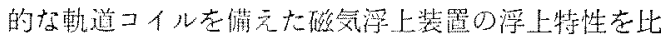
校检傠した。

\section{2. 解析方法}

磁気浮上装置のコイル配置，各部の寸法記号求よび 座標系 $(x, y, z),\left(x^{\prime}, y^{\prime}, z^{\prime}\right)$ の上り力は第1图の上㧍 りとする。車上コイル，軌道コイルはと屯に2 列に配 置さ扎ており，車上コイルはN極，S極上交互の極性 に励磁されている。

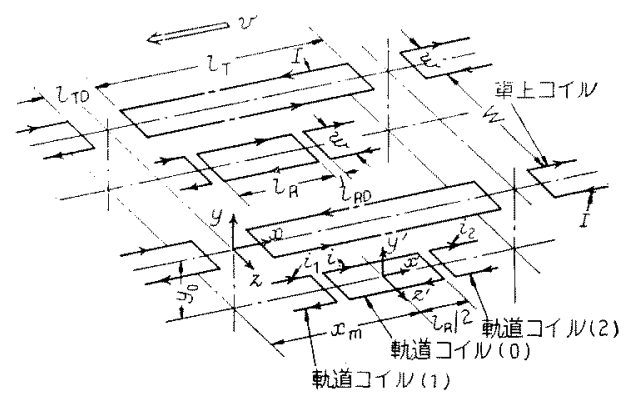

第 1 図 磁気浮上装置のコイル權成図

Fig. 1. Coil configuration of magnetic suspension system for high speed trains. 
〈2.1〉計算式磁気浮上力は㝵上コイルが作る 磁界上轨道コイルに唀起さ扎る電流との相互作用によ り生じる。軌道コイル誘起される雷流を記述する基智 方程式は，次式で与えられる。

$$
L \frac{d i}{d t}+R_{i}-\Sigma M_{j} \frac{d i_{j}}{d t}=-\frac{d \phi}{d t}
$$

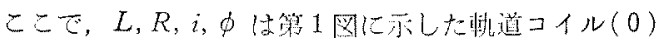
の自己インダクタンス，抵抗，䍴起電流，鎖交磁束で 古る。また $M$ ，は電流 $i$ ，方流机てい当軌道コイル (j) 亡轨道コイル $(0)$ の閒の相互インダクタンスであ って，これは良来の文献(3)ては整視されているもの である。この相互インダクタンス $M_{j}$ のちちで，軌道

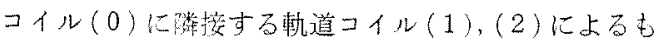
の批較的大きく， こ扎比心他の轨逆コイルによる

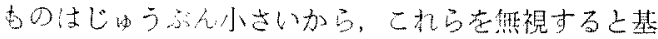
硞方程式（1)式は次の上うになる。

$$
\begin{aligned}
& L \frac{d i}{d t}+R i-M \frac{d i_{1}}{d t}-M \frac{d i_{2}}{d t}=-\frac{d \phi}{d t} . \\
& \text { ただし, } M_{1}=M_{2} \equiv M
\end{aligned}
$$

列車の編成数加多く，事上コイルはN極， S 極上交 互に無限に続いていると仮定*すると，申は一般的に 次式で表わされる。(実際のコイル配置に対する中お 上びフーリエ係数 $A F_{n}$ の導出法は付録工参照)

$$
\phi=\sum_{n=1}^{\infty} A F_{n} \sin n\left(\omega t+k x_{m}\right) \text {. }
$$

ただし

$$
\begin{aligned}
& \omega=\pi v / l_{T P} \\
& k=\pi / l_{T P} \\
& l_{T P}=l_{T}+l_{T D}
\end{aligned}
$$

ここで, ひは列車の速度であって，lTP は軒上コイル の1ピッチ長である。

(2)式で表加される中を(1')式代代入して電流 $i$ を求るる。iは(2)式と同様に次のような級数で表現 できる。

$$
i\left(t, x_{m}\right)=\sum_{n=1}^{\infty} i_{n} \cos \left\{n\left(\omega t+k x_{m}\right)+p_{n}\right\}
$$

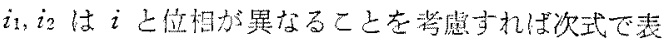
わさ机る。

$$
\begin{aligned}
& i_{1}=i\left(t, x_{m}-l_{R P}\right) \\
& i_{2}=i\left(t, x_{m}+l_{R P}\right)
\end{aligned}
$$

ここで, $l_{R P}$ 乾道コイルの1ピッチ辰である。

$$
l_{R P}=l_{R}+l_{R D}
$$

(2)，(4)，(5)式を(1') 式に代入すれば解 $i$ は次式

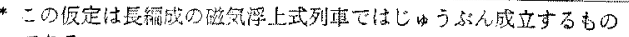
てある。
で与えられる。

$$
\begin{gathered}
i\left(t, x_{m}\right)=\sum_{n=1}^{\infty} 1 R^{2}+\frac{-V(n)}{(n \omega)^{2}(\bar{L}-2 M \cos n \phi)^{2}} \\
\quad \times \cos \left\{n\left(\omega t+k x_{m}\right)+p_{n}\right\} \quad \ldots \ldots \ldots \ldots(7) \\
\text { ここで, } V(n)=A F_{n} n \omega \\
p_{n}=\tan ^{-1}-n \omega(L-2 M \cos n \phi) / R \\
\phi=\pi l_{R P} / l_{T P}
\end{gathered}
$$

な㧍，春際の列車では $n_{R} \equiv l_{T P} / l_{R P}>3$ (後述) に選 定されること在考无る上，䊑道コイル間の磁気相互干 涉は誘起笔流 $i$ の基本波 $(n=1)$ に対する枕道コイル のインダクタンスを $L$ からら $L-2 M \cos \psi$ 亿低下さ 世る作用郁寸ることが( 7 )式加ら和る。

以上で轨道コイルに唀起される電流 $i$ が得られたの で，乙れを用いて次の上うにして浮上力，笔磁制動力 を求めることができる。車上コイル1個あたりの浮上 力 $F_{T}$ 扢よび霹磁制動力 $D_{T}$ は，列車編成 0 最前部 と最後部に生じる端効果を整視寺机ば，いずれの車上 コイルにおいても同一である。したがって，浮上力， 電磁制動力は車上コイル1個について考察する。

浮上力 $F_{T}$ 扰よび 電磁制動力 $D_{T}$ は 1 個の車上コ イルの下にある軌道コイルの数を $n_{R}$ とす扎，次式 で与えられる。

$$
\begin{aligned}
& F_{T}(t)=\sum_{m=1}^{n R} F\left(t, x_{m}\right) \\
& D_{T}(t)=\sum_{m=1}^{n R} D\left(t, x_{m}\right)
\end{aligned}
$$

ここで, $x_{m}=(m-1) l_{R P}$ であって, $F\left(t, x_{m}\right), D(t$, $\left.x_{m}\right)$ は軌道コイル 1 個あたりに生じる電磁力，電磁制 動力である。

$F\left(t, x_{m}\right)$ は勅道コイルに誘起される電流 $i$ 上車上コ イルが作る磁界 $B_{z}$ の積を軌道コイル上で線積分する ことにより得ら机，次式で表吅される。

$$
\begin{gathered}
F\left(t, x_{m}\right)=\int_{-l_{R / 2}}^{l_{R / 2}} i B_{z}\left(x,-y_{0}, w / 2\right) d x^{\prime} \\
\quad+\int_{l_{R / 2}}^{-l_{R / 2}} i B_{z}\left(x,-y_{0},-w / 2\right) d x^{\prime} \ldots(
\end{gathered}
$$

前述の仮定に上り， $B_{z}$ は $x$ について $2 l_{T P}$ を周期上 する周期閵数であり，次の上うに畾ける。(史際のコイ 儿配置に対する $B_{z}$ 占よびフーリ工係数 $A B_{j}(\%, z)$ の 尊出は付録 II 参照]

$$
B_{z}(x, y, z)=\sum_{j=1}^{\infty} A B_{j}(y, z) \sin j k x \ldots
$$

（11）式を（10）式に代入して皘分を実施す机ば， $F\left(t, x_{m}\right)$ は次の上う代算加る。 


$$
\begin{aligned}
& F\left(t, x_{m}\right)=i \sum_{j=1}^{\infty}\left\{A B_{j}\left(-y_{0}, w / 2\right)\right. \\
& \left.\quad-A B_{j}\left(-y_{0},-w / 2\right)\right\} \\
& \quad \times \frac{2}{j k} \sin j k l_{R} / 2 \sin j k\left(x_{m}+v t\right) \ldots \ldots
\end{aligned}
$$

こここ, 座殹系 $(x, y, z)$ 上 $\left(x^{\prime}, y^{\prime}, z^{\prime}\right)$ の間の周係

$$
\begin{aligned}
& x=x^{\prime}+v t+x_{m} \\
& y=y^{\prime}-y_{0} \\
& z=z^{\prime}
\end{aligned}
$$

を利用した。

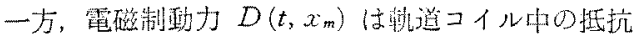
損 $i^{2} R$ に基ついて掩生するお口で，その大きさは次 式で与えられる。

$$
D\left(t, x_{m}\right)=i^{2} R / v
$$

〈2.2〉磁気浮上装置における電磁現象 前節で述

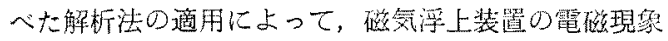
を完全に記述するとよができる。本節ではこの解析法 を具体的な列車モデルに邀用して，軌道コイル電流， 浮上力就よひ電磁骩動力の举動庄明らかにする。ここ で想定した列重モデルば一車車あたりの重量が $40 \mathrm{t}$, 一車闻長加約 $20 \mathrm{~m}$, 車雨幅力約 $4 \mathrm{~m}$, 一車雨古九り の車上コイル数が 4 個の委ので，最高速度を $500 \mathrm{~km} /$

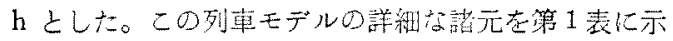
す。〔以下，当列事モデルを列事モデル(I)上呼引うな お同表中て $M$ はノイマンの公式(9)にって算出した 值であって，軦道コイルの時定数ては $i$ 基本波に 対する值である。

(a) 轨道コイル:榣起される霆流 $i$ 列車モデ

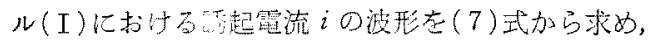
列車速度v苍パラータとして第 2 図儿示す。同図加

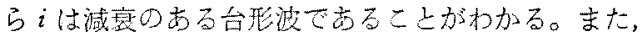

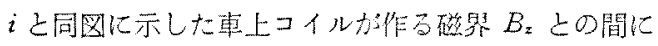
は位相差施生じているか，こ扎は(1)式に打ける抵抗 分 $R$ による屯のた，ขが小さいほよ゙，顕著に琾われ

\begin{tabular}{|c|c|c|c|}
\hline $\begin{array}{l}I=2 \times 10^{5} \mathrm{AT} \\
l_{R D}=0.08 \mathrm{~m} \\
\phi=1.0472 \mathrm{rad} \\
W=2 \mathrm{~m}\end{array}$ & $\begin{aligned} l_{R} & =3.25 \mathrm{~m} \\
M & =0.098_{\mu} \mathrm{H} \\
\tau & =0.5 \mathrm{~m} \\
R & =25.4 \mu \Omega * *\end{aligned}$ & $\begin{array}{l}L=3.93 \mu \mathrm{H} \\
l T D=1 \mathrm{~m} \\
z_{0}=0.25 \mathrm{~m} \\
n R=3\end{array}$ & $\begin{array}{l}l \tau=9 \mathrm{~m} \\
r=0.04 \mathrm{~m}^{*} \\
\tau=0.151 \mathrm{~s}\end{array}$ \\
\hline 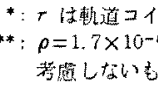 & 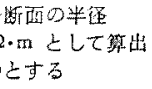 & $\bar{z}$, & 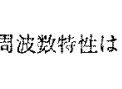 \\
\hline
\end{tabular}
る。

(b) 磁気浮上力第3困は浮上力の計算結果を 示したものである。同龱で $F_{T}$ は車上コイル1個に衙 く浮上力，Fは轨道コイル 1 個に斯く電磁力であって

第 1 表 列車モデル(I) の定数裴

Table 1. List of dimensions of train model (I).

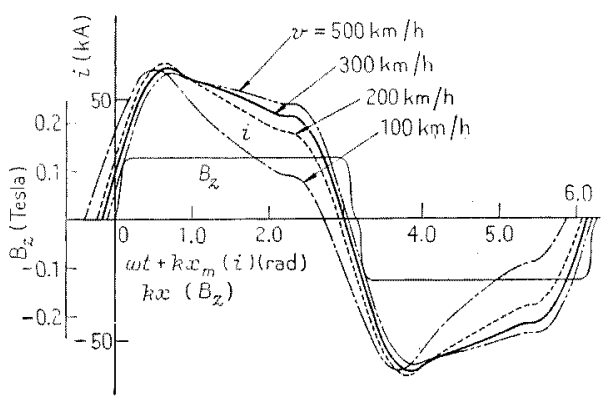

第 2 図 $i$ と $B_{z}$ の波形

Fig. 2. Wave forms of $i$ and $B_{x}$.

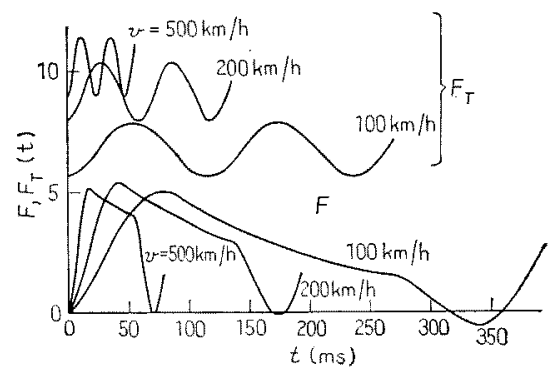

第 $3 \mathrm{Q}$ 深上力口波形

Fig. 3. Wave forms of magnetic lift forces.

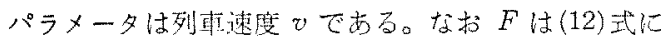

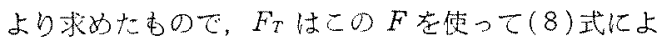
り求めた李のである。同図から明らかなように，曆上

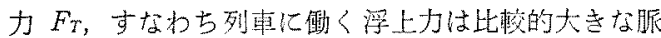
動分を有する。この脈動は土として䩚道コイルが離散 的であることに基ついて生じる6のであって，列車振 動の原因になる。なお脈㗢周波数 $f$ は

$$
f=v / L_{R P}
$$

で素和さ机る。一方，肫道コイルについて考えるむ，

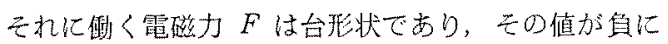

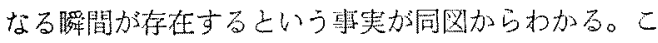
の臽の電磁力は列直に真の浮上力を生じさせるも車のて あって， $i 乞 B_{z}$ の間の位相差起因して現利れ，

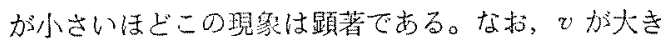
くなればこれはほ上んど睍わ机なくなる。

(c) 電磁制動力 電磁制動力を( 9 )式加求力 た。この結果第 4 四に示す。同图加ら明ら加な上う に電磁制動力は低速て極大值老持ち，乙の制動力口極 大值は磁気浮上列車を加速する際に問题になる。同図 で制動力の極大点より高速倒（2）は(1)式に晾いて $R$ の項老無視できる頜域であり，低整例（1）は $L$ の項 が無視できる㥧域である。

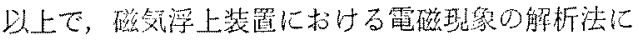
ついて述心゙，それによって舆体的な列車モデルの電磁 


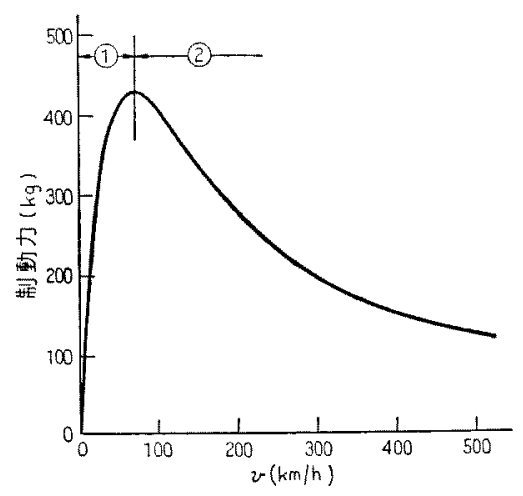

第 4 図 電磁制動力の速度依存性

Fig. 4. Magnetic drag force versus train velocity.

郳率を明らかにした。第 3 箱, 第4 章では浮上力, 天 の脈動および電磁制動力についてさらに詳細に検討す る。

\section{3. 浮上カとその脈動について}

浮上力は磁気浮上式超高速列車に扔いて最屯基本的 なるのであり,その眽動は列車振動に関連して重要で ある。ここでは浮上力およびこの脈動代対する磁気浮 上䒾置の設計諸元の影響を詳細に解明し，良好な浮上 特性，すな⿰七浮上力を大きく，その脈俥索小さくす る指針を明ら加化する。以下では設計諸元のうち，䇝 道コイル間のすきま $l_{R D}$ ，車上コイル間のすきま $l_{T D}$ (第 1 図参照)，軌道コイルの時定数 $\tau$, 軌道コイルの 個数 $n_{R}$ をとり上げる。

以下の考察で使用する眽動率 $F_{p f}$ を次式で定義す る。

$$
F_{P f}=100\left(F_{T(\max )}-F_{T(\min )}\right) / F_{T \text { average }}
$$

\section{〈3・1〉浮上力とその脈動に対する設計諸元の影響}

(a) 軌道コイル間のすきま $l_{R D}$ 列車モデル (I) で $l_{R D}$ の值が変化すれば $F_{T}, F_{p}$ がどのようになる 加を調へたたが第 5 図である。ここで，パラメータは 列車速度vであり，列車モデルの幾何学的諸元はモデ ル (I)の場合之同一であり，電気的諸元は $l_{R D}$ の㕠化 を考虑して決めた。同図からわかるように， $l_{R D}$ が小 さいはよ゙浮上力は大きくなり，脈動率は $l_{R D}$ が小さい ほよ゙小さくなる。したがって，構造上可能な限り $l_{R D}$ を小さくすることが浮上特性の点で望ましい。

(b) 軌道コイルの時定数 轨道コイルの時定数 て は轨道コイルの抵抗，インダクタンス，お上びそう 入リアクトルのインダクタンスによって決まる。その

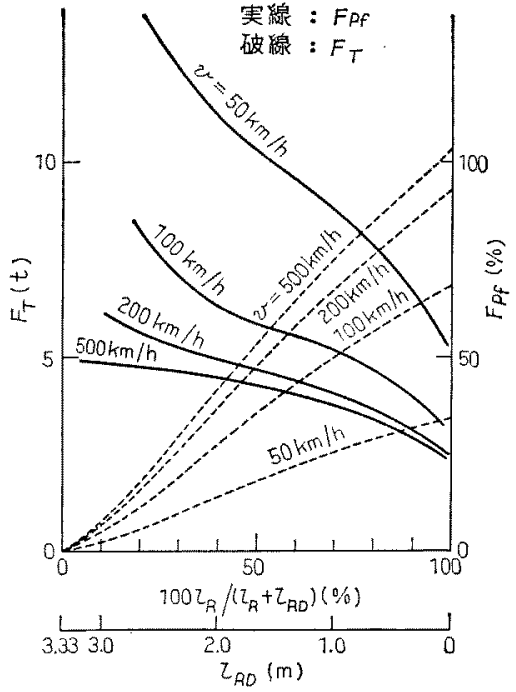

列車もデル(I)では $l_{R}+l_{R D}=3.33 \mathrm{~m} \quad 100 l_{R} /\left(l_{R}+l_{R D}\right)=97.6 \%$

第 5 図 浮上力上脈動率 $0100 l_{R} /\left(l_{R}+l_{R D}\right)$ 依存亚生

Fig. 5. Magnetic lift force and its pulsation factor versus $100 l_{R} /\left(l_{R}+l_{R D}\right)$.

選定は軌道コイルシステム上最も重要な因子であるか ら，この影響について述べるここでてはのの基本 波に対する等価的インダクタンス $(L-2 M \cos \psi)$ につ いて定義する。すなわち，

$$
\tau=(L-2 M \cos \psi) / R
$$

$\tau$ を変化させる方法として䩚道コイルの(1)インダク タンス $L$ を变化させる， (2) 抵抗 $R$ を变化させる, の2方法がある。まず, インダクタンスによっててを 变化させた場合の浮上力拉よび脈動率を, $500 \mathrm{~km} / \mathrm{h}$ K ついて第 6 図浲線で示す。この場合、インダクタン スを大きくす机ば誘起電流が制限されるから，浮上力 $F_{T}$ は $\tau$ の增大とと屯に減少する。方, 脈動率 $F_{p s}$ は $\tau \geq 0.1$ の領域では $\tau$ によってほ上んじ変化しない ことは注目すべきことである。

次に抵抗 $R$ によりてを変化させた場合の浮上力を 同じく $500 \mathrm{~km} / \mathrm{h}$ の速度について第 6 図に破線で示し た。同図から明らかなように， $\tau \gtrsim 0.15$ の領域では浮 上力は $R$ に上ってほ上んど变化しないが，て<0.15の 領域では $R$ の增加とともに浮上力は減少する。服動 率 $F_{p f}$ は $L$ を变化させたときの $F_{p f}$ (同図実線) と ほほ同一である。

以上の速度一定 $(v=500 \mathrm{~km} / \mathrm{h})$ の考察に引き続き以 下では速度を可变にした場合の $\tau$ の浮上特性に対する 影筙について検討する。

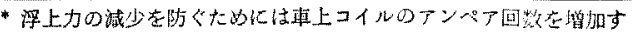
机より。 


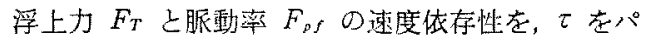
ラメータとして亦したのが䈀7图，第8図である。こ こで $L, R$ い゙れを可变と考えてもよい。*学上力 $F_{T}$ 仕てが小さいほ上゙速度に対する依存性が大きくなり， 脈勤率 $F_{p f}$ はてが大きいぼなさくなる。なお，

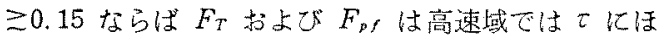
とんじ依存しないこと加同図からわかる。

〈3.2〉脈動に対する考察 前述加らかかる上う に浮上力の脈動は電流減衰によるあの上，浮上装置の 幾何学的形状によるものしがある。高速では脈動率は てにはとんよ゙依存しないので，前者の影留は小さい。 ここでは後者に関して，その詳絸を明らかにしたい。

隣接する 3 個の軌道コイルに生じる電磁力 $\left(F_{1}, F_{2}\right.$,

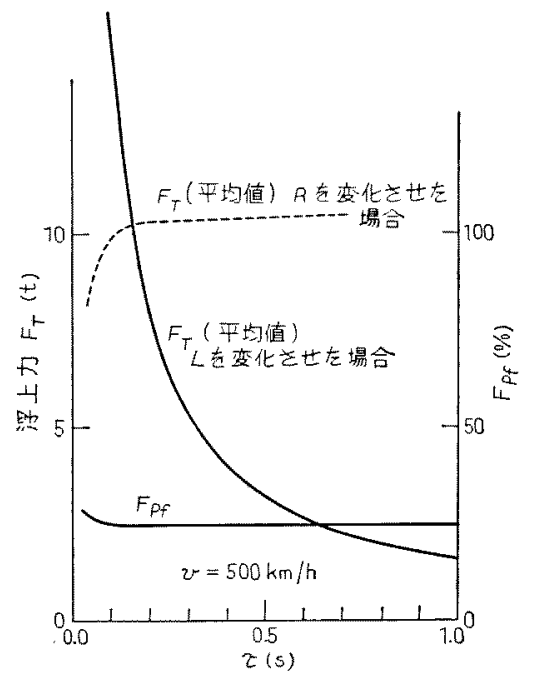

第 6 图 浮上力之その脈勘率の $\tau$ 依存性

Fig. 6. Magnetic lift force and its pulsation factor versus $\tau$.

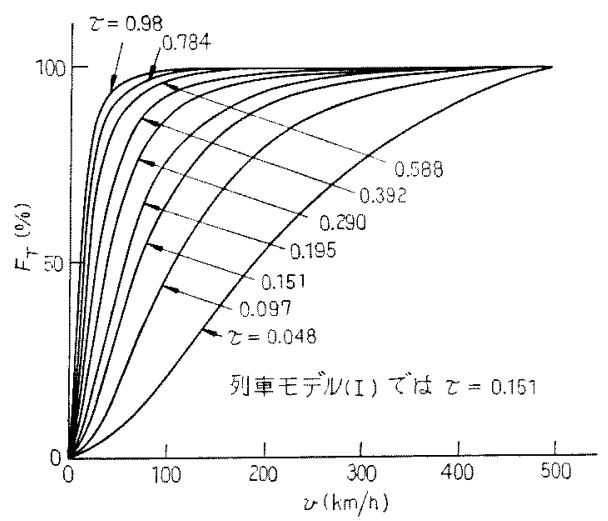

第 7 图浮上力の速度依存性

Fig. 7. Magnetic lift force versus train velocity.
$F_{3}$ 上それらの和で婊わされる車上コイル1個あたり の浮上力 $F_{T}$ を第 9 四に图式的に示した。同図で轨道 コイルに生じる震磁力が零から最大值に達するのに姴 する㭙間は $\left(l_{R} / 2+S_{1}\right) / v$ であり，䠊接する2 個の軌 道コイルに生じる電故力間の位相差（時間）は $l_{R_{p}} / v$ である。

なお，S は車上コイルの形状，浮上高さによって 決まる値であって，列車モデル（I）のように，lT》 $l_{T D}, w, y_{0}$ の上は， $S_{1}$ は $l_{T D}$ のオーダである。車 上コイル1個おたりに生じる浮上力 $F_{T}$ の波形は，上 述の雨時間 $\left(l_{R} / 2+S_{1}\right) / v$ 执よひ $l_{R P} / v$ の相刘閶係に よって，次の上うに分類される。

(a) $l_{R P} \geq 2 S_{1}+l_{R} \quad F_{T}$ の波形は第9図中の(1)

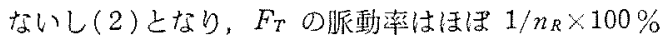

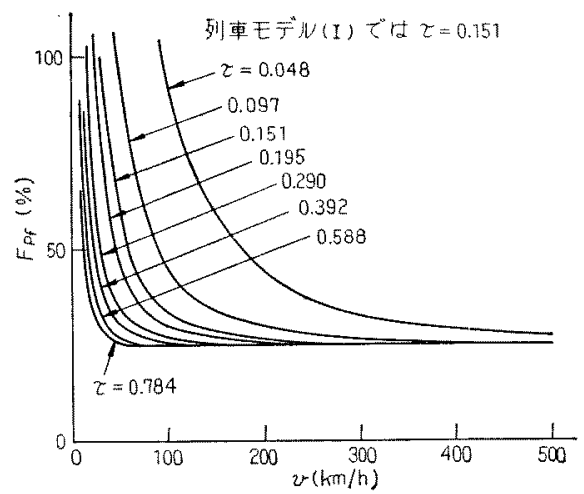

第 8 図 脈動率の凁度依存性

Fig. 8. Pulsation factor versus train velocity.

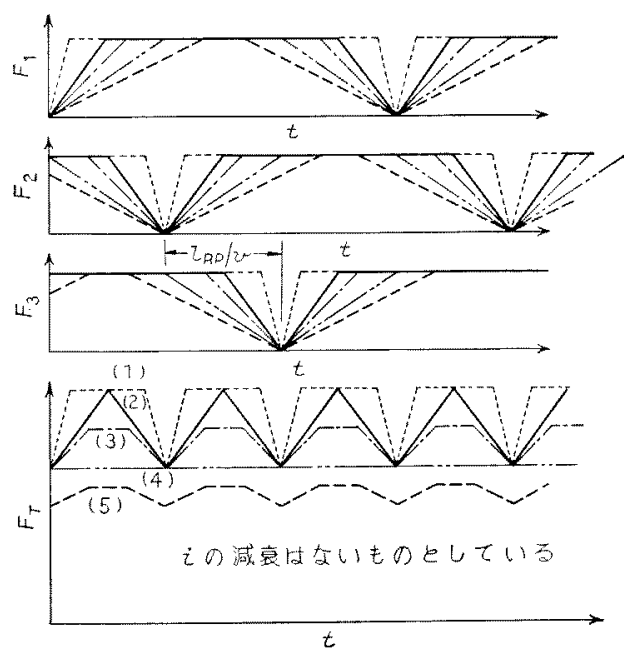

第 9 図目式的に表わした浮上力波形

Fig. 9. Schematic diagram of magnetic lift force.

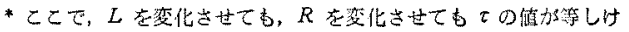
れば任话同一の速度饻存性をむつ。 
である。

(b) $2 S_{1}+l_{R}>l_{R P}>S_{1}+l_{R} / 2 \quad F_{T}$ O波北は(3)

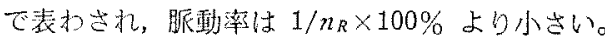

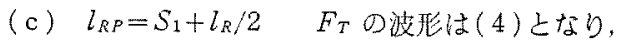
眽動渗は霍で苛る。

(d) $l_{R P}<S_{1}+l_{R} / 2 \quad F_{T}$ の没班は(5)であり，

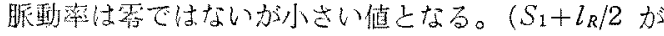
$l_{R P}$ 上り大きくなるに佂がって，F $F_{P f}$ は大さなりや がて極大值をしり，その後しだいに小さくなるな お，このとき漂上力も小さくなる。

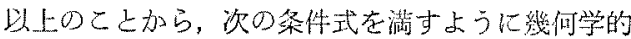

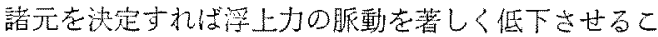
とができる。

$$
l_{R P} \leq S_{1}+l_{R} / 2
$$

この条件式は $S_{1}$ が $l_{T D}$ の閔数であること, $l_{R P}=l_{T P} /$

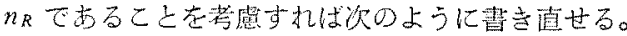

$$
l_{R D}+l_{T P} / n_{R} \leq 2 S_{1}\left(l_{T D}\right)
$$

上式で $l_{R D}$ は一般に小さい加ら，脈動在小さくする具 体的打策として次のことが考党られる。

(1) $n_{R}$ 大竟くする。

(2) $l_{T D}$ を大きくる。

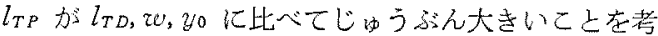
慮す机ば $S_{1}\left(l_{T D}\right)$ は片Dの才一ダになるから，派動 を小さくするためには $n_{R}$ を大光くする方策加最も効 果的であること少(19)式加ら予想される。

り下では具体的な列車モデルに上述の脈動をなくす る条件式(19)を適用してみる。

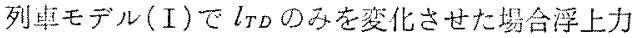
$F_{T}$ ，眽動率 $F_{P f}$ がよ゙のように変化するかを調べたの が第 10 图である。同図加ら明らかなようにl $\mathrm{m}$ で $F_{P S}$ は極小值をとるが，さらに $l_{T D}$ を大さく

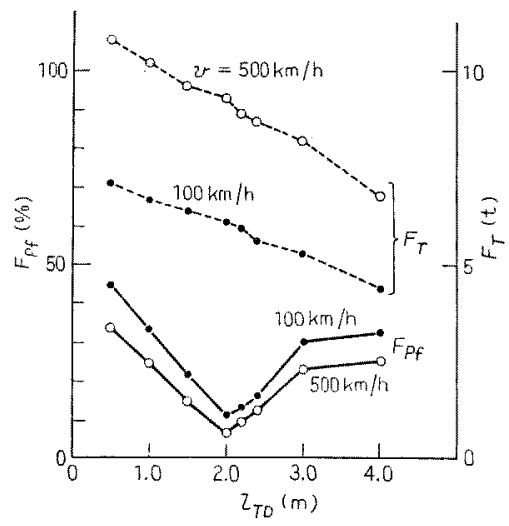

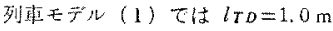

第 10 因 $F_{T}, F_{P f} O l_{T D}$ 依存性

Fig. 10. $F_{T}$ and $F_{P f}$ versus $l_{T D}$.
すれば $F_{P S}$ は增加する。これは 加D $_{T}$ ¿ $l_{T P}$ 加同才 一ダになれば，軌道コイル1個あたりに生じ石蝗磁力 が第9四に示したような台班状ではなくなってきて， 脈動をなく严る条件式 (19)の考え方を阔用できなくな るからである。また，浮上力は祝口の增加とともに減 少する。したがって，脈動率を小さくする方策として lTD 它大きするととは効果的でない。

次に列車モデル (I)で $n_{R}$ を変化させた場合の浮上 打 $F_{T}$ ，脈動率 $F_{P f}$ を示したの力笛 11 図である。こ こで, 列車モデルの幾何学的諸元は, 軦道コイル長 $l_{R}$ を除いては，列車モデル(I)と同一とした。轨道コイ ル長 $l_{R}$ 仕 $n_{R}$ に刘応して決定し $\left(n_{R}=l_{T P} /\left(l_{R}+l_{R D}\right)\right.$, $l_{T P}, l_{R D}$ は列車モデル(T)のモ机らと同じ), 䉓気的諸 元 $(L, R, M)$ は $l_{R}$ に対芯して新たに䚵算した。す なわち， $l_{R}$ の減少につれて， $L, R, M$ は減少してい る。同図汃ら明ら加なように， $n_{R} \geq 6$ であ机ば, 条件 式(19)肪満足さ机脈動率 $F_{P S}$ はじ: になる。

また，浮上力 $F_{T}$ は $n_{R}$ の增加とともに增加しさら に $n_{R}$ 老堌加すると今度は減少しはじかる。これは $n_{R}$ の增加につれて轨道コイルの自己インダクタンス が減少し， $F_{T}$ が増加すること， $n_{R}$ の増加につれて $l_{R} / l_{R P}$ の偲（ここでは $l_{R D}=0.08 \mathrm{~m}$ である）が減少 して $F_{T}$ が減少すること(第 5 図参照) および前述の (d)項で述べたように $F_{T}$ が隇少すること〔第 9 图の 波形(5)参留了のためである。

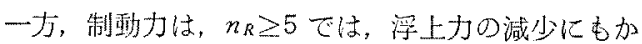

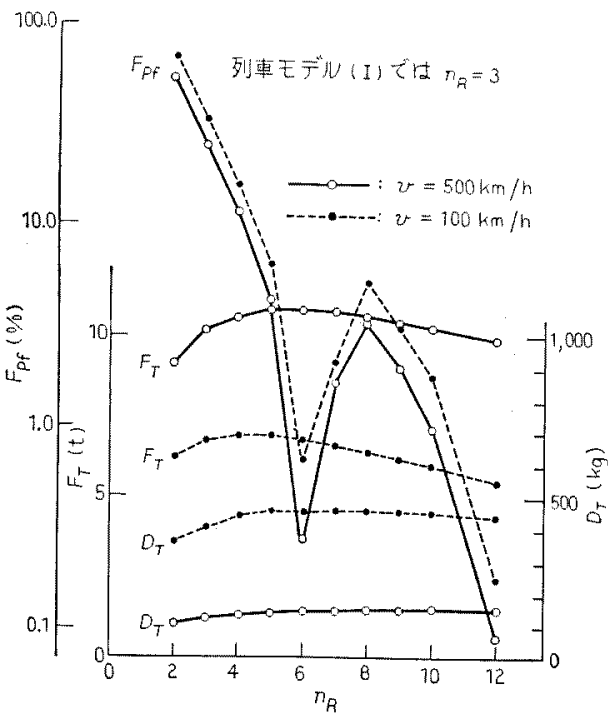

列本モت゙ル（I）では $n_{R}=3$

第 11 这 $F_{T}, F_{P_{S}}, D_{T}$ ○ $n_{R}$ 依存性

Fig. 11. $F_{T}, F_{P f}$ and $D_{T}$ versus $n_{R}$. 
かわらずほとんど減少せず（浮上力/制動力）の比は低 下する。これは $n_{R}$ が大きくなると軌道コイルのうち で列車進行方向に重直な部分（浮上力を発生せず制動 力のみを発生する部分) の占める割合が增えるためで ある。な打軌道コイルの時定数 $\tau は n_{R}$ の增加につ れて小さくなる。

\section{4. 電磁制動力}

〈2・2〉節で明らかにしたように，電磁制動力 $D_{T}$ は 低速域で極大值をとり，二の極大值は高速域の制動力 の値の数掊以上でちる。このような現象は列車を加速 する際闆題になるが，これまではあまり取り扱加和 れていない。ここでは，電磁制動力の速度傎存性につ いて議論する。

電磁制動力 $D_{T}$ ○速度依存性に影響老及保寸磁父浮 上装置の設計諸元は，軌道コイルの抵抗 $R$ および夷 効インダクタンスで決まる軌道コイルの時定数であ る。〔(7)，(9)，(14)式参照〕したがって，軌道コイル の時定数 $\tau[\equiv(L-2 M \cos \phi) / R]$ 名パラメ一タとして 列車モデル（I）にお放電磁制動力の速度低存性を第 12 図に示す。ここで， $R, L$ のいずれを可変と考えて 古上い。同図加ら明ら加ように低速域化現和机る電 磁制動力の極大檤は $て \geq 0.15$ であれば $\tau$ の影響をほ とんと受りないか，高速域の電磁制動力の值はてに依 存し，てを大きくす机減少する。次汇䉓磁制勳力の 極大値，この極大值が現和れる速度および $=500 \mathrm{~km} /$ $\mathrm{h}$ に求注る電磁制動力の値のて依存性を示したのが 第 13 図である。

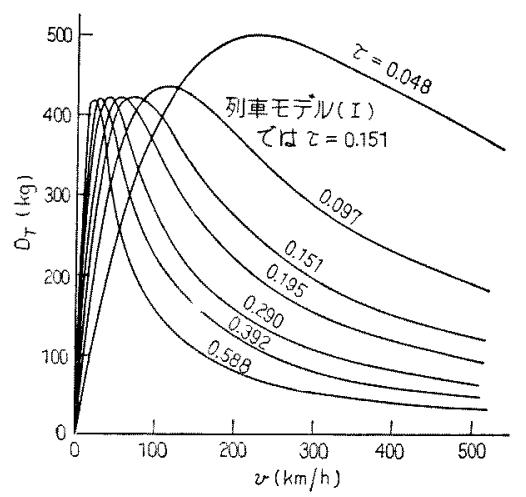

ه币のよ゙のケースについてる $v=500 \mathrm{~km} / \mathrm{h}$ の之 きのFrが 10tになるように車上コイルのアン ヘラ回数夻調整してある。

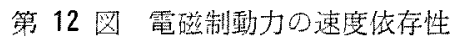

Fig. 12. Magnetic drag force versus train velocity.

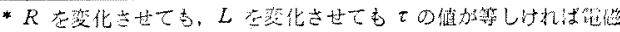

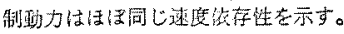

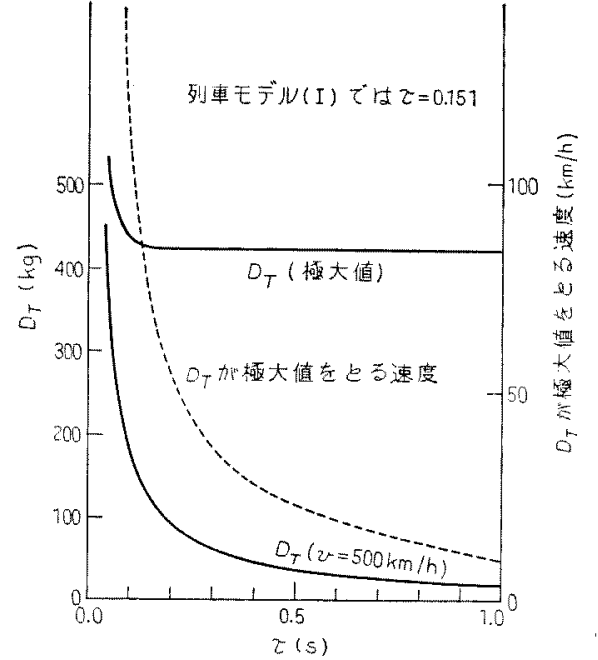

第 13 図 電磁制動力の $\tau$ 依存性

Fig. 13. Magnetic drag force versus $\tau$.

同図から，電磁制䣦力の極大徝は $\tau \geq 0.15$ 領域では てを大きくしてもほとんど隇少しないことがわかる。

一方，この極大值が現和机る速度はて注大きく依存 し，て在大きくするはじ小さくなる。なお， $v=500 \mathrm{~km} /$ hに甫りる電磁制動力は $\tau$ の値を大きくす机ば著し く隇少する。

以上の考察加らわかるように奏用的な螌围内で軌道 コイルの抵抗を滅少させるとか，インダクタンスを增 加させることにより電磁制怔力の極大值を隇少させる ことはできない。電磁制動力の極大值を小さくし，列 車の加速を容䀛にするたわには低速時だけ車上コイル のアンペアターンを減少させるか，補助車輪などによ り低速時だけ浮上高さを高くするこ上により轨道コイ ルの誘起電流を減少させ，轧道コイルの抵抗提失を減 少させる必要がある。

\section{5.はしご形軌道コイル}

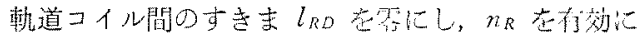
大きくする方式として第 14 图にしたようなはしご形

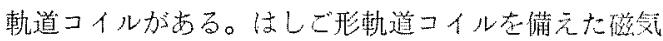
浮上装䈯では $l_{R D}=0$ 上みなせる加ら揵来の鹤散的な

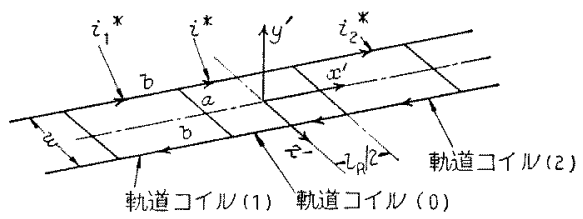

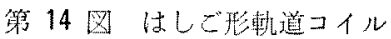

Fig. 14. Ladder type track loop. 
軦道コイルを借えた磁気浮上装置に比べて，浮上力は 大きくなり，脈動率は小さくなる。(符 5 图参照)

また，赖道コイルの短絡部( a ) (第14 図参照) 飞流 れる電流は $n_{R}$ が大きくなれば，ほとんよ゙雾に近づく

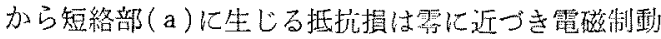
力が堿少する。なお轨道コイルをはしご形にす机ば軌 道コイルの製作が容易になるとと本利点の一つであ る。ここははしご形軌道コイルを有する磁気浮上装置 の浮上特性の解析法拉よび列車モデルの浮上特性につ いて述べる。

$\langle 5 \cdot 1\rangle$ 電磁現象の解析法第 1 図した磁気浮上 装置に扮いて，軌道コイルを第 14 図に示したはしご 形軌道コイルで置き換えて考えると，はしご形軌道コ イルに誘起さ机る電流を記述する基檚方程式は，次式 で与えら机る。

$$
\begin{aligned}
& L \frac{d i^{*}}{d t}+2 R_{0} i^{*}+\left(i^{*}-i_{1}^{*}\right) R_{s}+\left(i^{*}\right. \\
& \left.\quad-i_{2}^{*}\right) R_{s}-\sum_{j} M_{j} * \frac{d i_{j}^{*}}{d t}=-\frac{d \phi}{d t}
\end{aligned}
$$

ここで， $R_{0}$ ははしご形軌道コイルの (b) の部分の抵 抗, $R_{s}$ 短絡部 $(\mathrm{a})$ の抵抗であって, $R=2\left(R_{0}+R_{s}\right)$ である。また $i^{*}, i_{1}{ }^{*}, i_{2}{ }^{*}, M_{j}{ }^{*}, i_{j}^{*}$ は第 2 章で述べた $i, i_{1}, i_{2}, M_{j}, i_{j}$ に対応するものである。

第 2 章で行なったように $M_{1}{ }^{*}=M_{2}^{*}=M^{*}, M_{j}^{*} \simeq 0$ $(j=3,4, \cdots \cdots)$ とす机は（20)式は次の上うに帮ける。

$$
\begin{gathered}
L \frac{d i^{*}}{d t}+2 R_{0} i^{*}+\left(i^{*}-i_{1}^{*}\right) R_{s}+\left(i^{*}-i_{2}{ }^{*}\right) R_{s} \\
-M^{*}\left(\frac{d i_{1} *}{d t}+\frac{d i_{2}}{d t}\right)=-\frac{d \phi}{d t} \ldots(21)
\end{gathered}
$$

第 2 章と同様にして $i *$ を求めると， $i^{*}$ は次式で表 わされる。

$$
\begin{aligned}
i^{*}\left(t, x_{m}\right)= & \sum_{n=1}^{\infty} \frac{-V(n) \cos \{n(\omega t+}{V\left\{2 R_{0}+2 R_{s}\left(1-\cos n \phi^{\prime}\right)\right\}^{2}} * \\
& * \frac{\left.\left.k x_{m}\right)+p_{n}^{*}\right\}}{+(n \omega)^{2}\left(L-2 M^{*} \cos n \phi^{\prime}\right)^{2}}
\end{aligned}
$$

ここで

$$
\begin{aligned}
& V(n)=A F_{n} \times n \omega \\
& p_{n}{ }^{*}=\tan ^{-1} \frac{-n \omega\left(L-2 M^{*} \cos n \phi\right)}{2 R_{0}+2 R_{s}(1-\cos n \phi)} \\
& \phi=\pi l_{R P} / l_{T P}
\end{aligned}
$$

(22)式からわかるように，軦道コイルをはしご形に したために，轨道コイル1個むたりの等佂抵抗は $R \equiv$ $2 R_{0}+2 R_{s}$ 加ら $2 R_{0}+2 R_{s}(1-\cos n \psi)$ に減少してい る。車上コイル1個すたりに生じる浮上力は（8)， (12) 式て $i$ の代和りに $i^{*}$ を使えば求まる。一方，車

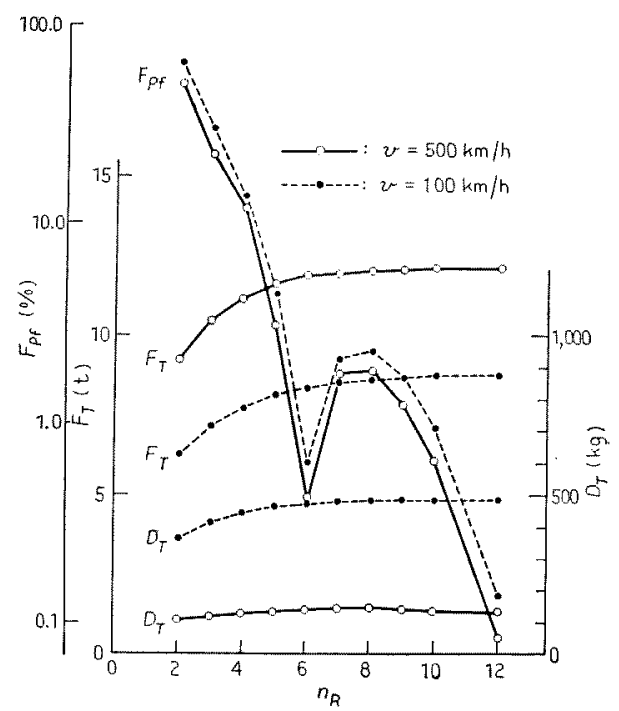

第 15 図 $F_{T}, F_{P f}$ および $D_{T}$ の $n_{R}$ 依存性 (はしご形軌道コイル)

Fig. 15. $F_{p}, F_{P f}$ and $D_{T}$ versus $n_{R}$ (ladder type track loop).

上コイル 1 個あたり生じる電磁制動力は $(9)$ 式で $D$ $\left(t, x_{m}\right)$ の代わりに次式で表わされる $D^{*}\left(t, x_{m}\right)$ を使 えば求まる。

$$
\begin{aligned}
D^{*}\left(t, x_{m}\right)= & 2 R_{0} i^{* 2}+\frac{1}{2} R_{s}\left\{\left(i^{*}-i_{1}^{*}\right)^{2}\right. \\
& \left.+\left(i^{*}-i_{2}{ }^{*}\right)^{2}\right\} \ldots \ldots \ldots \ldots \ldots \ldots
\end{aligned}
$$

ただし，

$$
\begin{aligned}
& i_{1} *=i^{*}\left(t, x_{m}-l_{R P}\right) \\
& i_{2}{ }^{*}=i^{*}\left(t, x_{m}+l_{R P}\right)
\end{aligned}
$$

$\langle\mathbf{5}$-2 $\rangle$ 浮上特性 前節で述へた計算式を使用し て、はしご形軌道コイルを借えた磁気浮上装置の浮上 特性を具体的に計算し，離散的机道コイルを備えた磁 気浮上装置の浮上特性上比較检討してみよう。列車乇 デル（I）の軌道コイルをはしご形にした磁気浮上䒾置 の浮上特性を示したものが第 15 図である。同図と列 車モデル(I)の浮上特性を示した第 11 図を比較して みれとば服動率 $F_{P_{S}}$ ，䉓磁制動力 $D_{T}$ に関しては両図 にほんど差がみら机ない。しかしはしで形軦道コイル を借えた磁気浮上装置の浮上力 (第 15 图) は離散的轨 道コイルを绩只大磁気浮上装置浮上装置の浮上力（第 11图)より6大きい。特に $n_{R}$ が大のとき両者の差肪 大きくなる。これは，軌道コイルをはしご形にすれば 靲道コイル間の相互インダクタンス $M^{*}$ は, 従来の 軌道コイルにおける相互インダクタンス $M$ に比べて 大きくなるから，はしご形軌道コイルの1区分の実効 インダクタンスが小さくなり浮上力が増加すること， 
はしご形軌道コイルでは $l_{R D}=0$ とみなせるから 100 $l_{R} / l_{R P}$ は常に $100 \%$ であり， $n_{R}$ 古大きししても浮上力 は減少しないことによるものである。なお，はしご形 軌道コイルを鞴えた磁気浮上装置の (浮上力/制動力) の比は，離散的軌道コイルを借えた磁気浮上装置のそ れよりも大であって， $n_{R}$ を大きくする，轨道コイ ルの短絡部 (a)（第 14 図)に拈ける抵抗損が零に近つ 〈加ら〔(23)式参照〕， $n_{R}$ の増加とともに增加可る。

以上のここ加ら、はしご形軌道コイルを㑲えた磁気 浮上装置のほうが離散的な軌道コイルを倩えた磁気浮 上装置よりも浮上特性の面ですぐれているといえる。 なお，はしで形軌道コイルで $n_{R}$ を大きな值に選んで もははしご形乾道コイルとシート形軌道コイルは本質 的に異なる。これははしで形軌道コイルでは電流路を 制限しているのに対して，シート形軌道コイルではこ の制限がないからである。

\section{5.むすひ}

うず電流に上る反発力を利用した隊気浮上式超高速 列莗に扔いて，車上コイルが作る磁界分布，靲道コイ ルの鎖交磁束，軌道コイルの抵抗，インダクタンスお よび軌道コイル間の磁気相互干渉を㪟密に考慮して磁

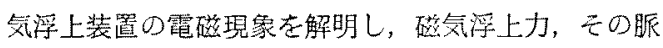
動および電磁制動力に対する磁気浮上装置の設計諸元 の影響について考察した。磁気浮上力は脈動のある直 流であり，この脈動は列車振動の原因になる。浮上力 の眽動は，車上コイル1個あたりの軌道コイルの数 $n_{R}$ を大きな值に巽へば，著しく減少することが判明 した。また，低速域の浮上力は軌道コイルの時定数 を大きくす机ば增大するということもわかった。

列車を加邀する際に問題になる電磁制動力は低速域 で極大値を上り，この極大值は軌道コイルの時定数 にほ上んど偖存しないということが明らかになった。 したがって，実用的な範围内で軌道コイルの抵抗 $R$ を減少させたりり，軌道コイルに外部りアクトルをそう 入したりしてもこの極大值を減少させることはできな い。なお，高速域の電磁制動力はこを大きくす机は著 しく減少する。

軌道コイルをはしご形にすれば，効率よく $n_{R}$ を大 きくでき，浮上力の脈勳の問題を解決できる。この場 合, 浮上力は従来の離散的な轨道コイル方式の磁気浮 上装置のこ机に比べて堌加する。

本稿を終抽あたりで指導をいただいだ当社， 伊藤, 大野各主任研究員および森川研究員に感謝致し ます。

(昭和 46 年 3 月 15 日受付, 同 46 年 8 月 7 日再受付)

\section{文献}

(1) A 300-m.p. h. Magnetically suspended train. I. R. C. A. p. $35(1968-3)$

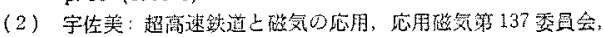
シン格ジウム聚料 (1971-1)

(3) J.R. Powell \& G.R. Danby: A. S. M. E. Paper 66-WA, RR 5

(4) I. R. Powell: Presented at 6 th Annual Meeting of Society of Engineering Science (1968) Princeton, N. J.

(5) H. T. Colfey \& E. Chilton: J. Appl. Phys. 40, P. 2161 (1969)

(6) J.R. Powell \& G. R. Danby: Published in Trans. Uth IECEC Conference, (1969) Washington, D.C.

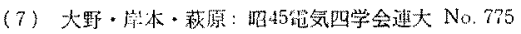

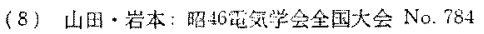

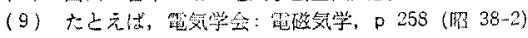

\section{付 録}

(I) 軌道コイル(0)の銷交磁束 $\phi$ を求めるだ に，まず，本文第 1 図中の車上コイル群のうちの1個 の車上コイルによる軌道コイル(0)の鎖交磁束 $\phi^{\prime}$ を 求める。/イマンの公式を使えば $\phi^{\prime}$ は次式で与えら 机可。

$$
\phi^{\prime}=\frac{\mu_{0} I}{4 \pi} \int_{c_{1}} \int_{c_{2}} \frac{d x d x^{\prime}+d y d y^{\prime}+d z d z^{\prime}}{V\left(x-x^{\prime}\right)^{2}+\left(y-y^{\prime}\right)^{2}+\left(z-z^{\prime}\right)^{2}}
$$

ここで，１は付第 1 図に示したように車上コイルに沿 った積分路であり，c2は軌道コイル(0)に沿った皘分 路である。また点 $(x, y, z)$ 皘分路 $c_{1}$ 上の点であり 点 $\left(x^{\prime}, y^{\prime}, z^{\prime}\right)$ は積分路 $c_{2}$ 上の点である。Iは車上コ イルの電流值である。

事上コイル，軌道コイルは上もに方形であること， 車上コイルが張る面上，軌道コイルが張る面が $x-z$ 平面に並行であることを考慮すれば(付 1 )式の積分は 求まり $\phi^{\prime}$ は次式で与えられる。

$$
\begin{aligned}
\phi^{\prime}= & \frac{\mu_{0} I}{4 \pi} \sum_{j=1}^{4} \sum_{i=1}^{4}\left\{F\left(x_{j}, y_{j}, z_{j}, x_{i}{ }^{\prime}, y_{i}{ }^{\prime}, z_{i}{ }^{\prime}\right)\right. \\
& \left.+F\left(z_{j}, y_{j}, x_{j}, z_{i}{ }^{\prime}, y_{i}{ }^{\prime}, x_{i}{ }^{\prime}\right)\right\}(-1)^{i+j}
\end{aligned}
$$

ここで

$$
\begin{aligned}
& F\left(x, y, z, x^{\prime}, y^{\prime}, z^{\prime}\right) \equiv-\left(x-x^{\prime}\right) \ln \left\{\left(x-x^{\prime}\right)\right. \\
& +\sqrt{\left.\left(x-x^{\prime}\right)^{2}+\left(y-y^{\prime}\right)^{2}+\left(z-z^{\prime}\right)^{2}\right\}}
\end{aligned}
$$

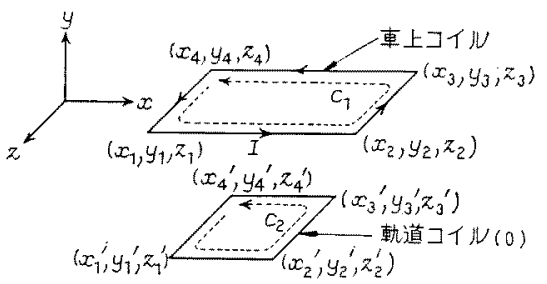

付第 1 図 1 個の車上コイルと軌道コイル(0) app Fig. 1. A train loop and the track loop (0). 


$$
+\sqrt{\left(x-x^{\prime}\right)^{2}+\left(y-y^{\prime}\right)^{2}+\left(z-z^{\prime}\right)^{2}}
$$

$x, y, z_{j}, x_{i}{ }^{\prime}, y^{\prime}, z_{i}{ }^{\prime}(j, i=1,2,3,4)$ は付第 1 因中に 示したように車上コイル，轨道コイル(0)0位圈を決 める座標である。

(付 2)式䘮利用すれば，本文中の第 1 図に示したよ うに，車上コイルが鿏限個存在する塌合の軌道コイル

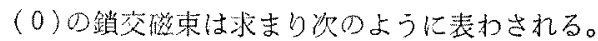

$$
\begin{aligned}
& \phi=\frac{\mu_{0} I}{4 \pi} \sum_{N=1}^{\infty} \sum_{K=1}^{2}\left[\sum _ { J = 1 } ^ { 4 } \sum _ { J ^ { \prime } = 1 } ^ { 4 } \left\{F \left(x_{N J}, y_{N J}, z_{N J},\right.\right.\right. \\
& \left.x_{J}{ }^{\prime}, y_{J^{\prime}}, z_{J}^{\prime}\right)+F\left(z_{N J}, y_{N J},\right. \\
& \left.\left.\left.x_{W J}, z_{J^{\prime}}, y_{J^{\prime}}, x_{J^{\prime}}\right)\right\}(1-)^{J+J}\right](-1)^{N+1} \\
& +\frac{\mu_{0} I}{4 \pi} \sum_{V=1}^{\infty} \sum_{K=1}^{2}\left[\sum_{J=1}^{4} \sum_{J^{\prime}=1}^{4}\{F(x \ldots, v, y-N J,\right. \\
& \left.\approx-N J, x_{J^{\prime}}, y_{J^{\prime}}, z_{J^{\prime}}\right)+F\left(z_{-N J}, y-N J\right. \text {, } \\
& \left.\left.\left.x_{-N J}, z_{J}^{\prime}, y_{J}^{\prime}, x_{J}^{\prime}\right)\right\}(-1)^{J+J^{\prime}}\right](-1)^{N}
\end{aligned}
$$

ただし，

$$
\begin{aligned}
& x_{N 1}=(N-1) l_{T P}+l_{T D} / 2, \quad x_{N 1}=x_{N 1}, \\
& x_{N 2}=N l_{T P}-l_{T D} / 2, x_{N 3}=x_{N 2}, \\
& y_{N 1}=y_{N 2}=y_{N 3}=y_{N 4}=0, \\
& z_{N 1}=w^{\prime} / 2-(K-1)(W+w), \quad z_{N 2}=z_{N 1}, \\
& z_{N 3}=-w^{\prime} / 2-(K-1)(W+w), \quad z_{N 4}=z_{N 3}, \\
& x_{-N 1}=-N l_{T P}+l_{T D} / 2, \quad x_{-N 4}=x_{-N 1}, \\
& x_{-N 2}=-(N-1) l_{T P}-l_{T D} / 2, x_{-N 3}=x_{-N 2}, \\
& y_{-N 1}=y-v_{2}=y-N 3=y-N 4=0, \\
& z_{-N 1}=w / 2-(K-1)\left(W+w^{\prime}, \quad z_{-N 2}=z_{-N 1},\right. \\
& z_{-N 3}=-w / 2-(K-1)(W+w), z_{-N 4}=z_{-N 3}, \\
& x_{1}^{\prime}=x_{m}+v t-l_{R} / 2, \quad x_{4}^{\prime}=x_{1}^{\prime}, \\
& x_{2}^{\prime}=x_{m}+v t+l_{R} / 2, \quad x_{3}^{\prime}=x_{2}^{\prime}, \\
& y_{1}^{\prime}=y_{2}^{\prime}=y_{3}^{\prime}=y_{4}^{\prime}=-y_{0}, \\
& z_{1}^{\prime}=w^{\prime} / 2, z_{2}^{\prime}=z_{1}^{\prime}, \\
& z_{3}^{\prime}=-w / 2, \quad z_{4}^{\prime}=z_{3}^{\prime}
\end{aligned}
$$

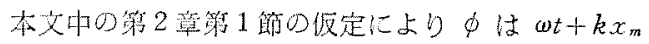

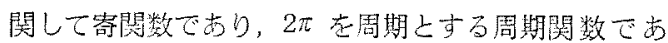
るから，一般的に次式で泰睍できる。

$$
\phi=\sum_{n=1}^{\infty} A F_{n} \sin n\left(\omega t+k x_{m}\right)
$$
たナ゙し，

$$
A F_{n}=\frac{1}{\pi} \int_{-\pi}^{\pi} \phi \sin n X d X
$$

なお，AFn は(付 5)式に(付 3)式で与总られる $\phi$ を 代入し，電子計算譏を使用して数值皘分をすることに より決定された。

(II) 一般に点 $\left(x_{1}, y_{1}, z_{1}\right)$ 加ら点 $\left(x_{2}, y_{2}, z_{2}\right)$ に に線分霹流(電流值 $I$ ) 肪流机ている亡き任意の点 $(x$, 》，z）に打ける磁界のz成分 $B_{z}^{\prime}$ は Biot Savart 式加ら求まり次式で表わされる。

$$
\begin{aligned}
& B_{z}(x, y, z)=\frac{\mu_{0} I}{4 \pi\left(y-y_{2}\right)^{2}+\left(z-z_{2}\right)^{2}} \\
& \int \frac{x-x_{2}}{1\left(x-x_{2}\right)^{2}+\left(y-y_{2}\right)^{2}+\left(z-z_{2}\right)^{2}} \\
& -\frac{\left(x-x_{2}\right)}{\left.1\left(x-x_{2}\right)+\left(x_{2}-x_{1}\right)\right\}^{2}} * \\
& \left.\frac{+\left(x_{2}-x_{1}\right)}{+\left(y-y_{2}\right)^{2}+\left(z-z_{2}\right)^{2}}\right] \\
& \equiv{ }_{4 \pi}^{\mu_{0} I} B Z F i x-x_{2}, y-y_{2}, z \\
& \left.-z_{2}, x_{2}-x_{1}\right)
\end{aligned}
$$

本文中の第 1 図に示した車上コイルは，4本の線分電

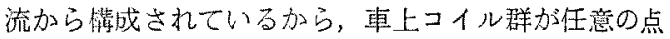
$(x, y, z)$ 亿作吕磁界 $\sigma \approx$ 成分 $B_{z}$ は（付 6 )式を利用 して求めることがで次のように㫪ける。

$$
\begin{aligned}
& B_{z}(x, y, z)=\frac{u_{0} I}{4 \pi} \sum_{N=1}^{\infty} \sum_{K=1}^{2}\left[B Z F \left(x-x_{N 2},\right.\right. \\
& \left.y-y_{N 2}, z-z_{N 2}, x_{N 2}-x_{N 1}\right)(-1)^{N+1} \\
& +B Z F\left(x-x_{N 3}, y-y_{N 3}, z-z_{N 3}, x_{N 3}\right. \\
& \left.-x_{N 4}\right)(-1)^{N}+B Z F\left(x-x_{-N 2}, y\right. \\
& \left.-y-N 2, z-z-N 2, x_{-N 2}-x_{-N 1}\right)(-1)^{N} \\
& +B Z F\left(x-x_{-N 3}, y-y-N 3, z\right. \\
& \left.\left.-z-N 3, x-N 3-x_{-N 4}\right)(-1)^{N+1}\right] \ldots \text { (t } 7
\end{aligned}
$$

ここで, $x_{N J^{\prime}}, y_{N J}, z_{N J}, x-N J^{\prime}, y-N J, z-N J\left(j^{\prime}=1,2\right.$, $3,4, J=2,3)$ は(付3)式で便用したものである。

$B_{x}$ 在本文中の (11) 式で表現した場合，フーリ工俰 数 $A B$ jは次式で表現さ机る。

$$
A B_{j}(y, z)=\frac{1}{\pi} \int_{-\pi}^{\pi} B_{z}(x, y, z) \sin j_{x} d x
$$

な扣フーリエ係数 $A B$ ；は(付8)式に(付7)式て 与えられる $B_{x}$ を代入し，電子詮算機を使用して数值 㿤分をするこしにより求めた。 